\title{
Pacific Salmon in the Rapidly Changing Arctic: Exploring Local Knowledge and Emerging Fisheries in Utqiaġvik and Nuiqsut, Alaska
}

\author{
Courtney Carothers, ${ }^{1,2}$ Todd L. Sformo, ${ }^{3,4}$ Shelley Cotton, ${ }^{1}$ John C. George ${ }^{3}$ and Peter A.H. Westley ${ }^{5}$
}

(Received 6 November 2017; accepted in revised form 29 January 2019)

\begin{abstract}
One of the most pervasive signals of global climate change is altered patterns of distribution with trends towards poleward shifts of species. While habitat loss and destruction has severed connections between people and salmon in many locales, salmon fisheries in the high Arctic are just beginning to develop. To explore these emergent connections, we gathered local knowledge about Pacific salmon and emerging subsistence salmon fisheries in the Beaufort Sea region through ethnographic research in Utqiagivik (formerly Barrow) and Nuiqsut, Alaska. Between 2010 and 2013, we interviewed 41 active fishermen and Elders who generally agreed that harvests of Pacific salmon species have been increasing in recent years, beginning in the 1990s and early 2000s. About $46 \%$ of active fishermen and Elders who discussed salmon abundance perceived an increasing trend over time. Another $43 \%$ characterized salmon abundance as cyclical or perceived no directional trend over time. The remaining fishermen (all from Nuiqsut) expressed their perception of decreasing salmon and fish abundance overall related to oil and gas development impacts to their local lands and waters. Given these mixed perceptions and harvests being an imperfect proxy for abundance, it remains unclear whether salmon populations are expanding in Arctic river systems. However, research participants have identified new stream systems not currently documented in the scientific literature where salmon are present and thought to be spawning. In both communities, we found that many fishermen and Elders often do not differentiate Pacific salmon species. Fishermen in both communities are developing new knowledge of salmon and increasing their use of salmon as a subsistence resource, yet uncertainties in the current data and local knowledge combine to generate equivocal evidence that salmon abundance is increasing. This lack of a clear increase in salmon abundance provides nuance to a simple story that warming has led to the increases of salmon in the Arctic. Despite the uncertainty regarding abundance, it is clear we are witnessing an emergence of new salmon fisheries in the high Arctic, perceived to be one among a suite of environmental and social changes currently being experienced in this region.
\end{abstract}

Key words: Arctic; climate change; Pacific salmon; subsistence fisheries; Iñupiaq fisheries; North Slope; Utqiagivik (Barrow); Nuiqsut

RÉSUMÉ. Un des signes les plus omniprésents du changement climatique à l'échelle mondiale se voit dans les modèles de répartition modifiés, les espèces affichant des tendances de déplacement vers les pôles. Même si la perte et la destruction d'habitats ont coupé les liens entre la population et le saumon en maints endroits, les pêcheries de saumon de l'ExtrêmeArctique ne font que commencer à se développer. Afin d'explorer ces liens émergents, nous avons recueilli des connaissances locales au sujet du saumon du Pacifique dans la région de la mer de Beaufort par le biais d'une recherche ethnographique à Utqiaġvik (anciennement Barrow) et à Nuiqsut, en Alaska. Entre 2010 et 2013, nous avons interrogé 41 pêcheurs actifs et ânés, qui s'entendaient généralement pour dire que les récoltes d'espèces de saumon du Pacifique ont augmenté ces dernières années, plus précisément depuis les années 1990 et le début des années 2000. Environ $46 \%$ des pêcheurs actifs et des aînés qui se sont entretenus de l'abondance du saumon avaient perçu une tendance à la hausse au fil des ans, tandis que $43 \%$ d'entre eux estimaient que l'abondance du saumon était cyclique, ou encore, qu'elle n'affichait aucune tendance directionnelle avec le temps. Les autres pêcheurs (tous de Nuiqsut) ont déclaré que dans l'ensemble, ils avaient l'impression que l'abondance de saumon et d'autres poissons diminuait en raison des incidences de la mise en valeur du pétrole et du gaz sur les terres et les cours d'eau de leur région. Compte tenu de ces perceptions mitigées et du fait que les récoltes ne constituent pas de bons témoins de l'abondance, il n'est toujours pas clair si les populations de saumon augmentent ou non dans les réseaux fluviaux de l'Arctique. Cependant, les participants à la recherche ont indiqué que de nouveaux réseaux hydrographiques non documentés dans les publications scientifiques comptent du saumon et que celui-ci semble frayer. Dans les deux collectivités, nous avons trouvé que de nombreux pêcheurs et aînés ne font souvent pas la différence entre les espèces de saumon du Pacifique. Les pêcheurs des deux collectivités acquièrent de nouvelles connaissances au sujet du saumon et intensifient leur usage du saumon comme ressource de subsistance. Cela dit, les incertitudes entourant les données actuelles et les connaissances locales s'allient

\footnotetext{
${ }^{1}$ College of Fisheries and Ocean Sciences, University of Alaska Fairbanks, 1007 W. 3rd Avenue, Suite 100, Anchorage, Alaska 99501, USA

${ }^{2}$ Corresponding author: clcarothers@alaska.edu

${ }^{3}$ Department of Wildlife Management, North Slope Borough, PO Box 69 Utqiaġvik, Alaska 99723, USA

${ }^{4}$ Institute of Arctic Biology, University of Alaska Fairbanks, 902 N. Koyukuk Drive, Fairbanks, Alaska 99775, USA

${ }^{5}$ College of Fisheries and Ocean Sciences, University of Alaska Fairbanks, 2150 Koyukuk Drive, Fairbanks, Alaska 99775, USA

(C) The Arctic Institute of North America
} 
pour prouver de manière équivoque que l'abondance du saumon augmente. L'absence de preuves claires en ce qui a trait à l'abondance du saumon vient nuancer une histoire simple selon laquelle le réchauffement se traduit par l'augmentation du saumon dans l'Arctique. Malgré l'incertitude concernant l'abondance, il est clair que nous sommes témoins d'une émergence de nouvelles pêcheries de saumon dans l'Extrême-Arctique. Cette émergence est perçue comme faisant partie d'un éventail de changements environnementaux et sociaux se manifestant dans cette région.

Mots clés : Arctique; changement climatique; saumon du Pacifique; pêcheries de subsistance; pêcheries de l'Iñupiaq; North Slope; Utqiagivik (Barrow); Nuiqsut

Traduit pour la revue Arctic par Nicole Giguère.

\section{INTRODUCTION AND BACKGROUND}

Warming of the global climate is rapidly transforming Arctic ecosystems (ACIA, 2005; Ford and Furgal, 2009; Hansen et al., 2012; Cochran et al., 2013; IPCC, 2014). Since the 1950s, air temperatures in the Arctic have increased by between $2^{\circ}$ and $3^{\circ} \mathrm{C}$ during summer and $4^{\circ} \mathrm{C}$ in winter, which translates to among the fastest rate of temperature change on Earth (ACIA, 2005; IPCC, 2014). Mean sea surface temperatures in the Beaufort and Chukchi Seas are increasing at a similarly rapid rate (Steele et al., 2010). Warmer air and sea temperatures contribute to a variety of physical changes, including but not limited to permafrost thawing, a reduction in summertime sea ice extent, decreasing sea ice thickness and loss of multiyear sea ice, glacial retreat, increased precipitation, decreased snow cover, increased riverine runoff, and increased organic carbon inputs to the Arctic Ocean from river systems (ACIA, 2005; Wassmann et al., 2011; Holmes et al., 2013). These environmental changes are correspondingly having pronounced effects on biological communities, with major trends of temperate species shifting northward (Parmesan et al., 2006; Cheung et al., 2013; Pinsky et al., 2013) likely to affect numerous fisheries in the Arctic (Laurel et al., 2016).

The modern-day distribution of Pacific salmon (Oncorhynchus spp., hereafter "salmon") represents a snapshot in the dynamic balance between local extinction and colonization (Schtickzelle and Quinn, 2007). Much of the current salmon range was claimed by individuals colonizing freshwater habitats following the retreat of glaciers at the end of the last glacial epoch (Hendry et al., 2004; Waples et al., 2008). In contemporary times, salmon have colonized newly available habitats that are provided by ongoing glacial recession (Milner et al., 2000) and reclaimed suitable habitat following restoration of access, such as dam removal or fish passage construction (Pess et al., 2014). The colonizing of suitable freshwater habitats, combined with site fidelity, contributes to the evolution of locally adapted stock complexes; these locally adapted stocks directly benefit human harvesters as fish abundance is buffered against environmental change (Hilborn et al., 2004; Schindler et al., 2010). Currently, global climate change, in conjunction with major habitat loss and destruction, imperils salmon in the southern end of their distribution and has eroded biological diversity, which results in fisheries collapse. Yet a warming Arctic is providing potential opportunities for northern range expansion by salmon (Nielsen et al., 2013). Barriers to salmon colonization include potential phenological mismatches between life history events in freshwater and the marine environment, such as the timing of when to go to sea or when to return to spawn. Additionally, competition with other marine species for favorable food sources such as zooplankton (Morita et al., 2001; Ruggerone et al., 2007; Moss et al., 2009) may impede successful colonization.

Our understanding of the historic and current abundance and geographic extent of Pacific salmon species in the Arctic region is limited (Logerwell et al., 2015). Some studies suggest that salmon species are increasing their abundance and range (e.g., Moss et al., 2009; Dunmall et al., 2013), while others caution against this conclusion as reports of salmon in the Arctic have been documented for over a century (Bockstoce, 1988; Stephenson, 2006). Five species of Pacific salmon have been observed in the Alaskan and Canadian Arctic, though only pink salmon (O. gorbuscha) and chum salmon (O. keta) have been documented to have natal populations sustaining small runs between Point Hope, Alaska, and the Mackenzie River (Irvine et al., 2009; Nielson et al., 2013). A total length of $3185 \mathrm{~km}$ of river has been documented to contain salmon in the Alaskan Arctic (ADFG, 2018a), with over 98\% of the length related to pink salmon and chum salmon, while Chinook salmon $(O$. tshawytscha), sockeye salmon $(O$. nerka), and coho salmon $(O$. kisutch) are very rare in Arctic waters and are likely not yet established populations (Nielson et al., 2013). Recent studies document an increasing presence of Chinook salmon and sockeye salmon species in the Beaufort Sea region, but it remains unclear if these recent data indicate an increase in abundance, a shift in range, a short-term anomaly, or increased attention and research in these systems (e.g., Riedlinger, 1999; Babaluk et al., 2000; Fechhelm and Griffiths, 2001; Stephenson, 2006; George et al., 2009; Irvine et al., 2009; Brown et al., 2016). Coho salmon are the rarest of all Pacific salmon in Arctic waters; only a handful of captures have ever been documented (Craig and Haldorson, 1986; Babaluk et al., 2000; Stephenson, 2006; George et al., 2009; Nielson et al., 2013). These patterns of species occurrence may reflect life history requirements; pink salmon and chum salmon rely on freshwater only for spawning, whereas the other species have extended periods of freshwater rearing prior to 
seaward migration. In either case, successful colonization by salmon necessitates matches between habitat conditions in both marine and freshwater ecosystems.

While the scientific literature is currently inconclusive about changing salmon abundance or patterns of colonization in the Arctic, recent studies suggest that catches and use of Pacific salmon species in the Arctic are increasing. Dunmall et al. (2013) show increasing trends of harvest in the western Canadian Arctic. These increased Arctic salmon harvests are noted in the North Slope of Alaska as well, such as in Utqiagivik (Cotton, 2012; Brown et al., 2016) and Wainwright (Mikow et al., 2016). In 2008 , for example, subsistence harvesters using gillnets in Elson Lagoon near Point Barrow recorded a catch of over 1500 pink salmon in their logbooks, with an estimated total for the 2008 harvest of pink salmon to be roughly between 5000 and 10000 fish (Lemke et al., 2011). In the same year, Fechhelm et al. (2009) reported that a record 284 pink salmon were caught in fyke nets at the Endicott Development, an oil field located about $16 \mathrm{~km}$ northeast of Prudhoe Bay, and stated that catches of pink salmon were increasing in the Itkillik River during fall subsistence fisheries that targeted other species. Salmon catches near Wainwright have increased, and locally rare species, such as Chinook salmon, are becoming more prevalent in subsistence harvests (Kassam et al., 2001; Mikow et al., 2016).

Iñupiaq Arctic residents who continue to live traditional hunting and fishing lifestyles deeply connected to lands and waters are among the most knowledgeable experts about their local environments and changes over time. Our intention in this project was to respectfully gather local and Indigenous knowledge to contribute to the state of knowledge about Arctic salmon shifts and emerging subsistence salmon fisheries in the Beaufort Sea region of Arctic Alaska. Our goal was to help document and share a body of knowledge that may help to inform science (but does not need to be validated by it), recognizing the many challenges that accompany this kind of work (e.g., Mistry and Berardi, 2016; Williams et al., 2016). Indigenous knowledge systems develop from the deeprooted relationships between human groups and the lands and waters they inhabit. Detailed environmental knowledge, effective practices for resource harvesting and management, and cultural beliefs are accumulated and passed down through the generations, often through oral transmission and experiential learning (Houde, 2007; Berkes, 2008). Indigenous knowledge systems are valid and time-tested. The Iñupiat have been sustainably stewarding their lands and waters for millennia based on these detailed knowledge systems.

Fishing has historically been, and currently is, an important subsistence mainstay for the Iñupiat of the North Slope region (Wolfe et al., 1986; Pedersen and Shishido, 1988; Craig, 1989; Burch, 1998; Brewster et al., 2008; Fall et al., 2017). Fish remain a major part of the modern diet and fishing is viewed as a vitally important subsistence activity that fosters family and community learning, cooperation, and sharing (Brewster et al., 2008). While some excellent studies on local and Indigenous knowledge of fish species in the North Slope region of Alaska have been conducted (e.g., Brewster et al., 2008), much of this information is not easily available (e.g., Arundale and Schneider, 1987). The continued documentation of local and Indigenous knowledge provides not only a valuable contribution to the state of knowledge about Pacific salmon in the Arctic and changes in the region, but also contributes to the understanding of the importance of subsistence fisheries for Iñupiat of the North Slope in the context of pronounced social-ecological changes (Brewster et al., 2008; Cotton, 2012; Brown et al., 2016; Mikow et al., 2016).

We conducted ethnographic research in Utqiagivik and Nuiqsut, Alaska with active fishermen and Elders. Our specific objectives were to: 1) learn from Iñupiaq experts and other local fishermen about their knowledge and perceptions of salmon abundance, distribution, and identification, and 2) document current and traditional uses of, and preferences for, salmon. We conclude the paper by situating perceptions about salmon in a larger context of environmental and social change in the high Arctic and sharing some poignant lessons learned from this study that may assist future researchers in this region and beyond.

\section{STUDY COMMUNITIES}

\section{Utqiagivik}

Utqiagivik is located on the coast of the Chukchi Sea, approximately $16 \mathrm{~km}$ south of Point Barrow, the northernmost point of the United States (Fig. 1). Utqiagivik is the administrative and economic hub of the North Slope region. As such, it is a diverse community and has a relatively large population of approximately 4300 people. According to the 2010 U.S. Census, approximately $61 \%$ of Utqiagivik residents identify as Alaska Native or American Indian (primarily Iñupiat), $17 \%$ as white, $9 \%$ as Asian, $3 \%$ as Hispanic, $2 \%$ as Pacific Islander, $1 \%$ as black, and roughly $9 \%$ identify with multiple racial backgrounds (U.S. Census Bureau, 2012).

Important fishing locations for Utqiagivik residents range from coastal areas near Wainwright to Teshepuk Lake and inland to the headwaters of the Chipp River (Fig. 1). According to George et al. (2009), there are over 20 fish species harvested in the Utqiagvik region (see Logerwell et al. (2015) for an assessment of fish communities extending from near- to offshore, and Moulton and Seigle (2012) for Elson Lagoon fish diversity). The primary species harvested by local residents include broad whitefish (Coregonus nasus), Arctic cisco (C. autumnalis), least cisco (C. sardinella), Arctic grayling (Thymallus arcticus), burbot (Lota lota), lake trout (Salvelinus namaycush) and Dolly Varden (Salvelinus malma). Various species of Pacific salmon are utilized as subsistence resources in Utqiagivik 


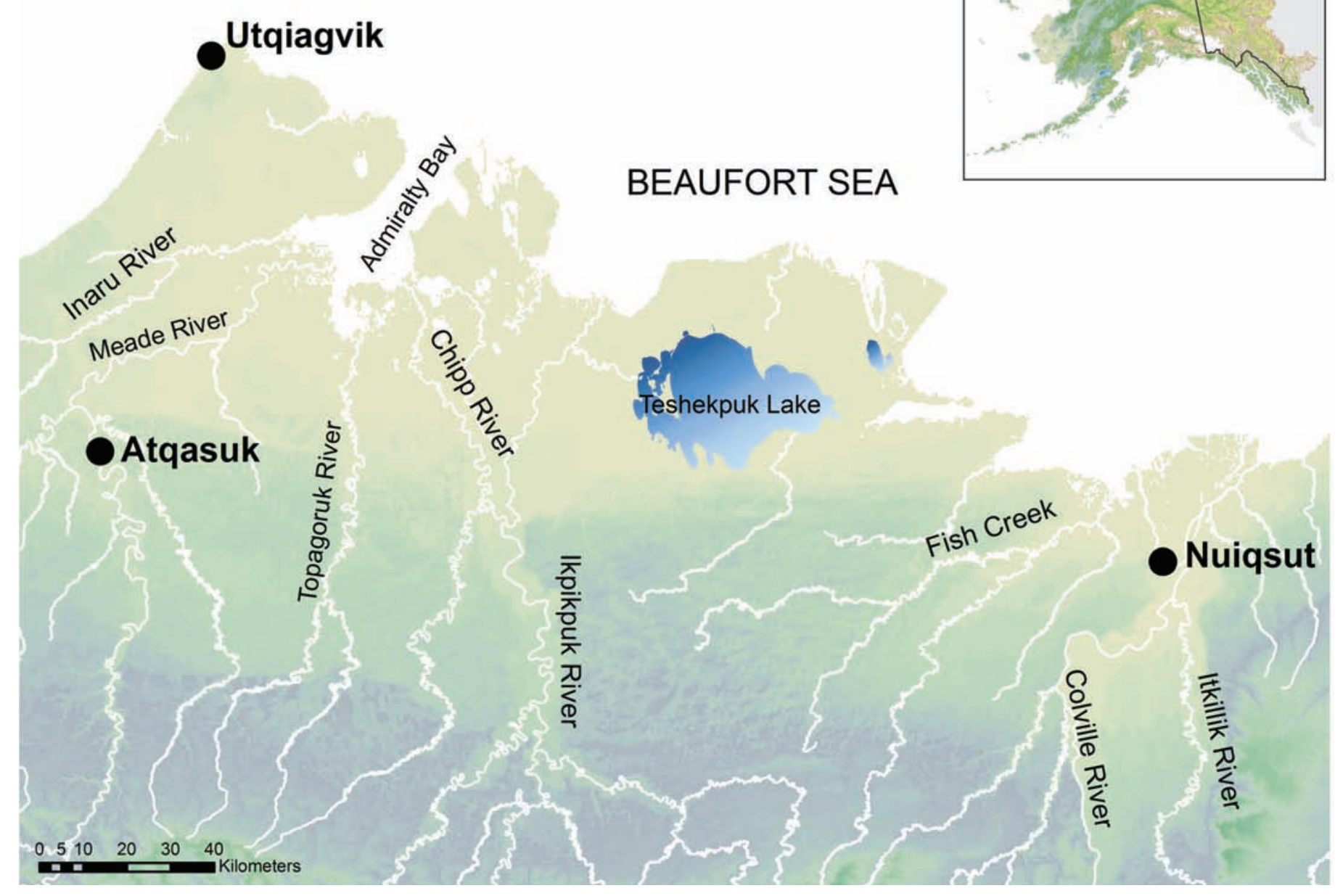

FIG. 1. The central North Slope Borough region showing Utqiagivik (formerly Barrow), Nuiqsut, and area waters. Map produced by Leslie Jones, University of Alaska Anchorage and Christine Woll, The Nature Conservancy.

and Nuiqsut, but are harvested in much smaller numbers and are relatively less important fisheries (Brewster et al., 2008).

To our knowledge, the earliest written account describing salmon harvesting near Utqiagivik was recorded during the summer of 1852. The account originated with Dr. John Simpson, Royal Navy surgeon on Her Majesty's Discovery Ship Plover, who made the observation during his two-year overwintering with Rochfort Maguire, captain of the Plover (Murdoch, 1892; Bockstoce, 1988). Simpson overwintered in Nuvugaluak or Plover Pass, Elson Lagoon, near Point Barrow. His essay is a separate account but is included in the Rochfort Maguire journal. Dr. Simpson notes that the "... inlets and rivers yield them [the inhabitants from Point Barrow to Point Hope] the salmon, the herring, and the smelt, besides other kinds of small fish" (Bockstoce, 1988:504). Elson Lagoon was historically, and is currently, utilized for harvesting fish on their seasonal migrations. Between the months of July and September, Elson Lagoon-located about $10 \mathrm{~km}$ from Utqiagivik — supports a growing subsistence gill net fishery. The majority of salmon caught by Utqiagivik residents are harvested in this fishery, but they are also caught incidentally in river fisheries (Brewster et al., 2008; George et al., 2009; Cotton, 2012). In 2011, 362 chum (42\% of catch; 70\% by weight) and 196 pink salmon ( $23 \%$ of catch; $11 \%$ by weight) made up the majority of the recorded $1427 \mathrm{~kg}$ summer Elson Lagoon catch (Cotton, 2012), which is consistent with recent years (Lemke et al., 2011). Catches of salmon were reported from mid-July to mid-September.

Pink salmon, chum salmon, and Chinook salmon are utilized by people in the Utqiagivik area, but are harvested in relatively small numbers compared to cultural staple fish species like whitefishes and ciscoes (Brewster et al., 2008; Stephen R. Braund and Associates, 2010; Cotton, 2012; Brown et al., 2016). The number of households harvesting salmon has increased in the last few decades, as has the reported harvest of salmon. In the $1980 \mathrm{~s}$, only between $1 \%$ and $10 \%$ of Utqiagivik households were estimated to harvest salmon and during this period salmon harvest made 
up between $0.2 \%$ and $3.0 \%$ of total fish harvests (ADFG, 2018b). In the 2000s, Stephen R. Braund and Associates (2010) estimated that about $12 \%$ of Utqiagivik households were harvesting salmon; on average, they estimated that each household in Utqiagivik consumed only about $0.5-1 \mathrm{~kg}$ of salmon per year. According to their estimates, salmon harvests made up about $5.8 \%$ of the total subsistence fish harvest by weight. By 2014, Brown et al. (2016) recorded that $24 \%$ of households in Utqiagivik harvested salmon and $69 \%$ of households used salmon (although these estimates included local harvest, as well as harvests elsewhere in Alaska). They reported that salmon made up 23\% of all fish harvested, $3 \%$ overall of all subsistence harvested (by weight).

\section{Nuiqsut}

Nuiqsut is a small village of about 434 residents located approximately $56 \mathrm{~km}$ from the Beaufort Sea coast $(243 \mathrm{~km}$ from Utqiagvik), and situated on the west bank of the Nechelik (Nigliq) Channel of the Colville River (Fig. 1). The community, which is located in the homeland of the Kukpikmiut (the People of the Lower Colville River), was resettled by 27 families in 1973 and formally incorporated as a second class city in 1975 (Brogan, 1979). According to the 2010 U.S. Census, about $87 \%$ of Nuiqsut residents identify as Alaska Native or American Indian (primarily Iñupiat), $10 \%$ as white, $0.3 \%$ as black, and $2.7 \%$ of multiple racial backgrounds (U.S. Census Bureau, 2012).

As in Utqiagivik, fish are an important subsistence resource for the community of Nuiqsut, typically ranking as third in total harvest after bowhead whale (Balaena mysticetus) and caribou (Rangifer tarandus) (Brown et al., 2016). Nuiqsut fishermen use set nets as their primary mode of catching fish and also jig with hook and line for species such as burbot. They primarily harvest Arctic cisco, broad whitefish, and Dolly Varden in their nets (Stephen R. Braund and Associates, 2010). Nuiqsut residents typically harvest salmon within the Colville River delta and drainage, the Itkillik River, and Fish Creek regions. Salmon historically comprise a very minor portion of the subsistence fish catch in this community (Fechhelm et al., 2009). In 1985, salmon were estimated to make up only $0.6 \%$ of the total fish harvest, and in $1993,0.4 \%$. In a 2014 estimate of harvest, $24 \%$ of total subsistence harvest was made up of fish species, only $1 \%$ of which comprised salmon species (Brown et al., 2016).

\section{METHODS}

Prior to conducting ethnographic research, we developed relationships with, and received formal project endorsement from, the Native Village of Barrow, the Native Village of Nuiqsut, the North Slope Borough Fish and Game Advisory Committee, and the Kuukpik Subsistence Oversight Panel. We conducted ethnographic field research between 2010 and 2013 (a total of 43 days were spent in Utqiagivik and 23 days in Nuiqsut). We presented our research results and a draft of our initial results to each of the entities listed above and in public community meetings in Utqiagivik and Nuiqsut. These meetings, which included the participation of many of the local experts who participated in this study, provided an opportunity to clarify and refine our findings.

Local experts in each community were identified using purposive, snowball sampling methods (Bernard, 2006). Community leaders recommended knowledgeable, active, and long-time fishermen. Those individuals then recommended other knowledgeable and active fishermen. In Utqiagvik, we interviewed 23 local experts: 18 men and 5 women. In Nuiqsut, we interviewed 18 local experts: 14 men and 4 women. In both communities, the ages of our key respondents ranged from mid-40s to mid-80s, with the exception of one interview with a group of three younger fishermen, aged 23-40, in Nuiqsut. We did not purposively sample for geographic range of fishing experience; collectively, our suite of respondents shared knowledge about the major marine and river systems located near their communities and their hunting and fishing camps spread across the region.

We conducted semi-directed ethnographic interviews (Spradley, 1979; Huntington, 1998) with these local experts. Specifically, we focused discussions on the importance of salmon compared to other species, subsistence fisheries for salmon, uses of salmon, and knowledge about salmon abundance, distribution, and life history (see Cotton, 2012 for interview protocol). We also asked about perceptions of change over time; generally, respondents discussed changes over the past several decades, but some older respondents discussed observations back to the 1940s. We provided local and regional maps during the ethnographic interviews to better enable experts to refer to places of interest as appropriate. With permission, interviews with key respondents were audiotaped and fully transcribed. Three interviews were conducted in Iñupiaq with the assistance of a translator. These interviews were translated and transcribed into English. Audio recordings and transcripts of interviews conducted with Elders were archived with their permission at the Inupiat History, Language and Culture Commission in April 2012.

In addition to ethnographic interviews, we utilized participant observation to gather details about subsistence fisheries in this region. Participant observation is a signature method of anthropological study, where researchers learn by doing (Bernard, 2006). We joined community members in fishing activities, community gatherings, meals, and other local events and activities. During participant observation, detailed notes were taken, discussion about catches occurred, and help was provided to pull in nets and pick fish that had been caught. We were able to visit gill net sites in Elson Lagoon to observe the summer subsistence fisheries in 2010 and 2011. We also observed several fish camps from the seasonal ice road along the Nigliq Channel in 2011 and participated in Nalukataq - the spring whaling 
festival-in Nuiqsut in June 2011, where fish are one of many foods shared with the community. Likewise, we visited fishing locations and camps along the Colville River in 2013, during the open water season.

After transcribing interview data, we thematically coded the text using the qualitative data analysis program, ATLAS.ti. A hierarchical thematic code list of primary and secondary codes was developed from Moerlein and Carothers (2012) and refined as we analyzed the interview text to allow for community- and context-specific codes to be developed. Once coding was completed, we produced code count tables (online Appendix 1), explored code co-occurrences, and generated lists of specific quotes for each code for further analysis (Bernard, 2006).

\section{RESULTS AND DISCUSSION}

\section{Salmon Abundance, Distribution, and Identification}

Study participants in both Utqiagivik and Nuiqsut generally agreed that salmon harvests have increased over time, beginning in the 1990s and early 2000s. This period corresponds with large total abundances of salmon in the North Pacific region (Ruggerone and Irvine, 2018) and may have contributed to the increase in harvest. As in the scientific literature, there are mixed opinions among fishermen and Elders about whether these increases in salmon harvest are indicative of an overall increase in salmon abundance. Perceptions of change in salmon abundance were specifically discussed by 28 of the 41 interviewees. About $46 \%$ of respondents who discussed salmon abundance perceived salmon abundance to be increasing. Another $43 \%$ characterized salmon abundance as cyclical or perceived no directional trend over time. A few Nuiqsut fishermen expressed their perception of decreasing fish abundance, resulting from oil and gas development impacts to their local lands and waters.

Elders in both Utqiagivik and Nuiqsut remembered catching salmon when they were young. One Elder stated that her family "first saw that salmon came up this far" (referring to an area east of Utqiagivik) in the late 1940s. She noted that her parents had no prior knowledge of salmon, but they made use of the new resource. Previous ethnographic works also document several Elders describing increasing salmon presence. For example, in 1982, Raymond Neakok stated that he began noticing an increase in salmon in local rivers near Utqiagivik (BLM, 1982: Appendix II:4, cited in Brewster et al., 2008). In 1988, Robert Aiken stated:

Salmon, they never used to come up here. In summertime, by our cabin, I got a net. And it started getting some salmon. Dog [chum] salmon. Real big toothed ones. Not very many of them. We never used to get them, but now we do, so maybe they start moving from some place.

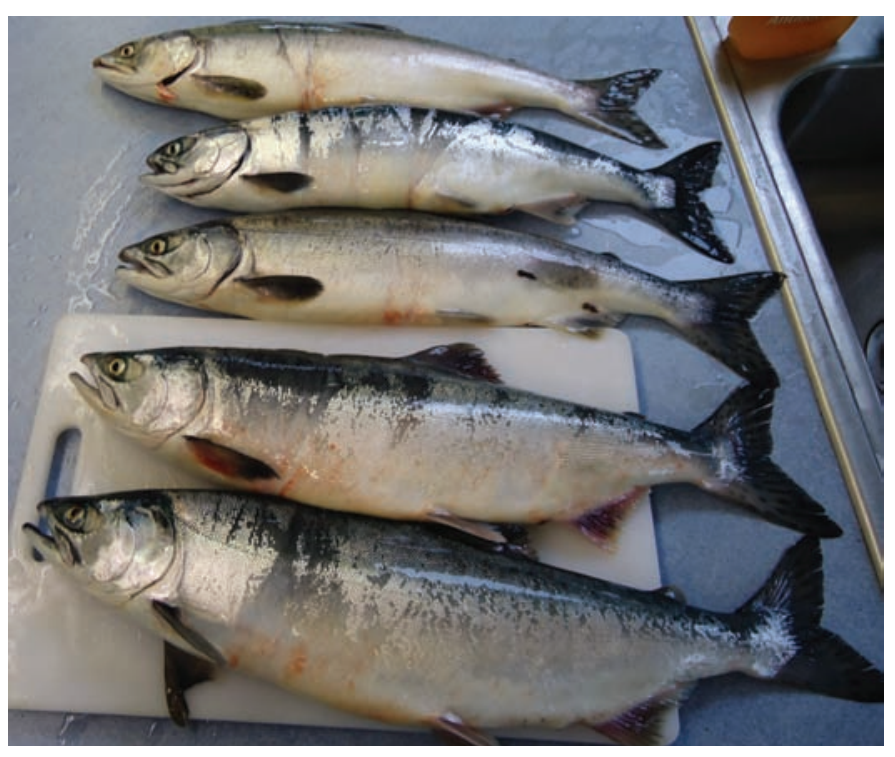

FIG. 2. A catch of pink salmon from Elson Lagoon, Utqiagivik, 21 July 2011. Photo: Shelley Cotton.

In another interview conducted in 1988, Sadie Neakok indicated that there were silver-colored salmon in the Ikpikpuk River, a species that she noted they are not used to fishing for (Neakok and Neakok, 1988). Several Elders in Nuiqsut noted that they were unsure about which Iñupiaq names to use to describe salmon because neither they nor their parents had observed, caught, or eaten salmon.

During our interviews in 2010, several fishermen noted that pink salmon had been plentiful to the point of being a nuisance by clogging their fishing nets in recent years (Fig. 2). One fisherman stated that fishing conditions have "...gotten to the point where there's too many pinks to deal with." Another noted: "We get more of the humpies [pink salmon], a lot of the humpies, and last two years there's been mostly humpies." For some fishermen, pink salmon are not a desirable fish to catch (as discussed further below); therefore, these increases are viewed negatively. Several local experts mentioned a notable increase in pink salmon abundance in the 1970s. This observation was confirmed by previous ethnographic investigation. For example, Brewster et al. (2008:62) provide the following quotation from Warren Matumeak:

We used to get lots of those amaqtuuq [pink salmon]. Still get them out in the rivers. They are noticeable when we get them in our net. We just throw them away. Leave them for the animals to feed on. Maybe after the 1970s, before the 1980s, we saw more of them. I used to leave the amaqtuuq and get the aanaaktiq [broad whitefish].... Amaqtuuq are a nuisance, they're not good at all. Can't eat them. Although people do eat them. They take the hump off and eat them. Iñupiat used to take that hump off and use it.

However, other fishermen and Elders cautioned that earlier generations knew about and caught salmon and did not 


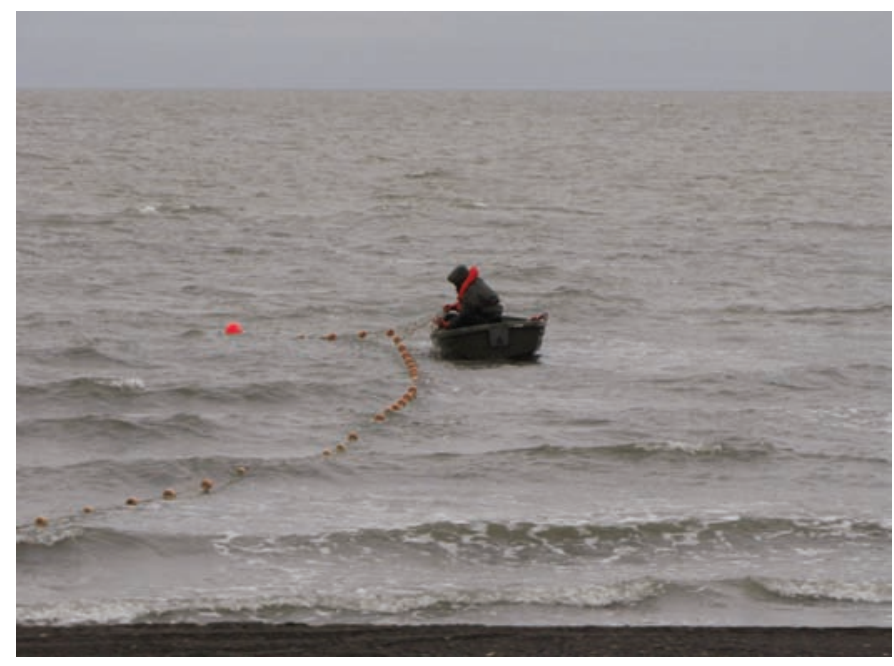

FIG. 3. Utqiagivik fisherman picking his gill net in Elson Lagoon, 15 August 2011. Photo: Courtney Carothers.

support the generalization that salmon populations are new or increasing in numbers in the region.

In Nuiqsut, several local experts discussed observing increasing pink salmon runs in the Itkillik River (Fig. 1). An older fisherman stated that when he was young, in the 1950s, pink salmon were driven from the Itkillik River because of development in that region. Another Nuiqsut fisherman observed that in recent years there "... [are] beginning to be a lot of pinks, especially on the Itkillik River." One fisherman with a fish camp at the mouth of the Itkillik River said that "thousands of pink salmon" started showing up in the river around 2005.

Chum salmon are regularly caught throughout the summer and early fall in the gill net fishery in Elson Lagoon in Utqiagivik (Figs. 3 and 4). Fishermen estimated that approximately 30 chum salmon can be caught per net, per day during the peak of the run (see Cotton, 2012). In Nuiqsut, however, the presence and abundance of chum salmon is less certain. One Elder, for instance, stated that he does not remember catching chum salmon at fish camps along the Colville River when he was young. Several other informants stated that chum salmon are a relatively recent migrant to the Colville and Itkillik River systems.

In Utqiagivik, researchers and residents alike have paid increasing attention to Chinook salmon presence in the region. One informant stated that a non-local recreational fisherman visiting Utqiagivik was reported to be the first to catch a Chinook salmon on a fishing rod in the 1990s. Locals also began fishing for Chinook salmon with fishing rods around this time. Another informant noted that he caught two Chinook salmon in 1992 that he estimated were both longer than a meter. One particularly active fisherman stated that he caught his first Chinook salmon in 2002 or 2003 and has only caught one other Chinook salmon since then. He noted that he mistook his first Chinook salmon for a seal before he pulled in his net. He used a harpoon to get the large Chinook salmon out of his net and into his boat. Some fishermen now use larger mesh gill nets during the

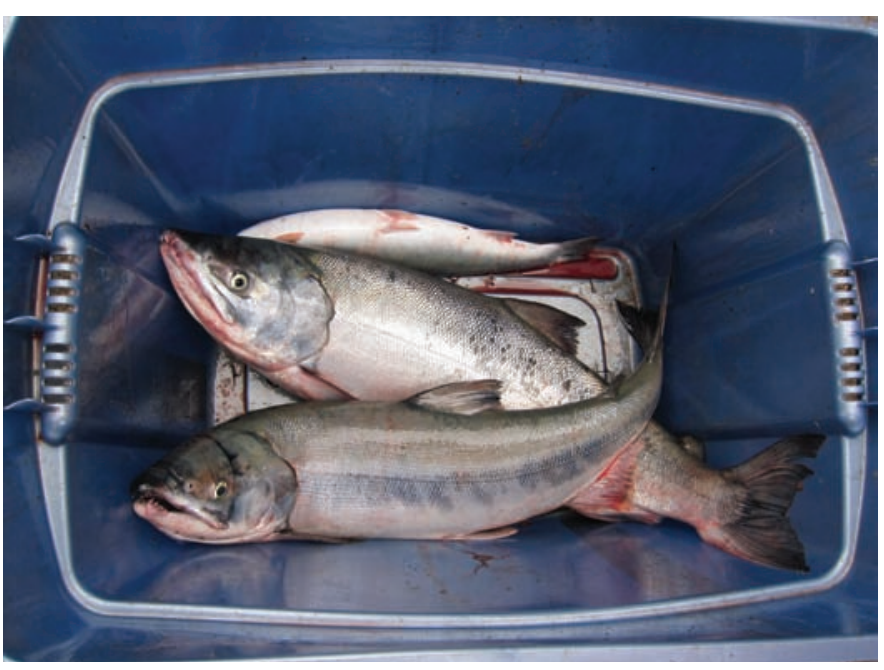

FIG. 4. A pair of chum salmon from Elson Lagoon, Utqiagivik, 20 August 2011. Photo: Courtney Carothers.

month of July to specifically target Chinook salmon. These changes in fishing practices (e.g., fishing with rod and reel and using larger mesh size nets) indicate that for some local residents, Chinook salmon are a desirable fish to catch.

Despite this increasing effort, Chinook salmon remains a relatively infrequently caught fish. Informants in both Utqiagivik and Nuiqsut stated that they usually harvest few, if any, Chinook salmon. Informants reported that generally fishermen who catch one or two Chinook salmon over the course of an entire summer fishing season are considered lucky. Data collected by the North Slope Borough Department of Wildlife Management (NSB-DWM) (Bacon et al., 2009) and interview data for this project both indicate that 2003 was a notable year, with Chinook salmon catches estimated to be over 200 fish. The years prior to 2007 were generally favorable to Chinook salmon production throughout Alaska, after which survival and abundance of many populations declined precipitously (Schindler et al., 2010). Due to issues associated with species identification, as described below, we were not able to generalize about the presence of sockeye and coho salmon species in this region from our interview data.

Nuiqsut informants confirmed the presence and possible spawning activity of pink salmon in the Itkillik River. One informant with a fish camp at the mouth of the Itkillik River reported that thousands of pink salmon started showing up in the Itkillik around 2005. He stated that they congregated in one spot and remained there $(4.8-6.4 \mathrm{~km}$; about 3-4 mi by his estimation, up the Itkillik River) (Fig. 5). Chum salmon were documented in the Ikpikpuk River (Fig. 6; see George et al., 2009:34). One informant reported that he caught one chum salmon in Ikroagvik Lake (connected to Iko Bay via Avak Creek) while fishing in mid to late October, just after the lake had frozen over. Local records confirm that in October 2012, two sockeye salmon were caught in Ikroagvik Lake (G. Carroll, pers. comm. 2012) and one sockeye salmon was caught in October 2013 (R. Sarren, pers. comm. 2013). Genetic analysis at 
Pink Salmon

- Presence documented by ADFG

Spawning documented by ADFG

_ Spawning documented by George et al. (2009) or informants

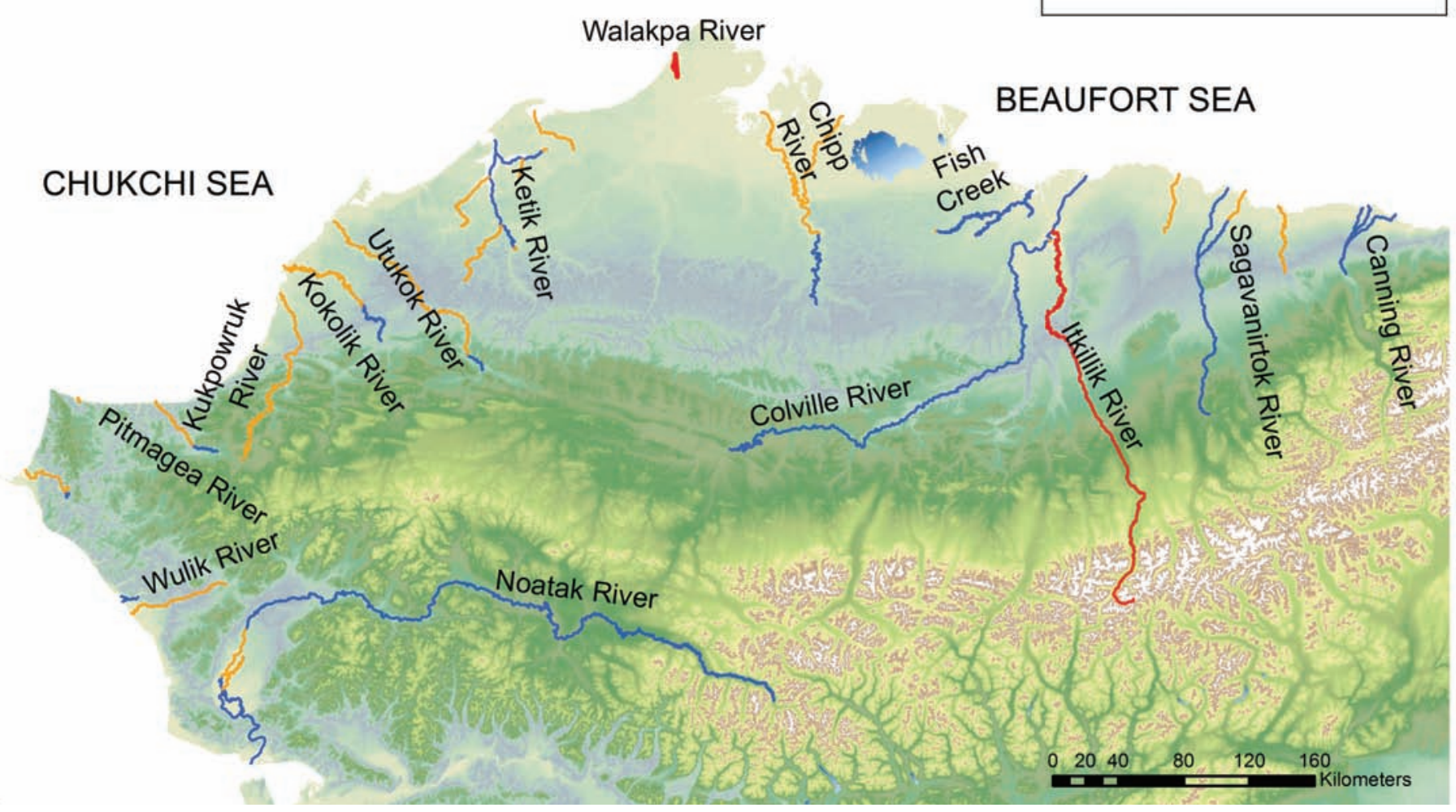

FIG. 5. The presence and spawning of pink salmon in stream systems in the North Slope region. Map produced by Leslie Jones, University of Alaska Anchorage and Christine Woll, The Nature Conservancy.

the University of Alaska also confirmed these fish were sockeye salmon (Andrés López, pers. comm. 2011). Nuiqsut informants confirmed the presence and potential spawning of chum salmon in the Itkillik River, as well as the presence of chum salmon in Fish Creek.

Because salmon are relatively less important than other more common local fishes, informants tended to know less about these species. We found identification issues arose during our interviews, and misidentification of the particular salmon species contributes to inconsistent catch data and increases overall uncertainty. In both study communities, we found that active and knowledgeable fishermen were not comfortable identifying salmon at the species level, which in itself is suggestive of the relatively recent arrival of salmon in appreciable numbers. In Nuiqsut, we found conflation of salmon species and Dolly Varden among some study participants.

During our participant observation in summer 2011 in Utqiagivik, many fishermen showed us their catches while picking their nets. Ocean chum salmon, still in their marine coloration, were often called "silver" salmon (another common name used for coho salmon in other regions, but similar to the use of the term "silver" for fall chum salmon in the Yukon River communities). Utqiag vik fishermen catch their fish in brackish water, when salmon are still a brilliant silver color; as such, the use of the term "silver" in reference to chum salmon seriously challenges the validity of reporting of "silver" to mean coho salmon caught in subsistence fisheries in both the U.S. and Canadian Arctic (e.g., NPFMC, 2009; Mikow et al., 2016). We also found that several informants tended to refer to large chum salmon as "king" salmon (another common name for Chinook salmon), also adding to uncertainty in trends of abundance. We found that pink salmon, especially in spawning condition, tended to be identified correctly more often than chum salmon. This may be due to the differences in size, scale size, texture of flesh, prominence of the dorsal hump in mature males, and distinctive spotting patterns on the back and caudal tail. 


\section{Chum Salmon}

Presence documented by ADFG

Spawning documented by ADFG

Presence documented by George et al. (2009) or informants

Spawning documented by George et al. (2009) or informants
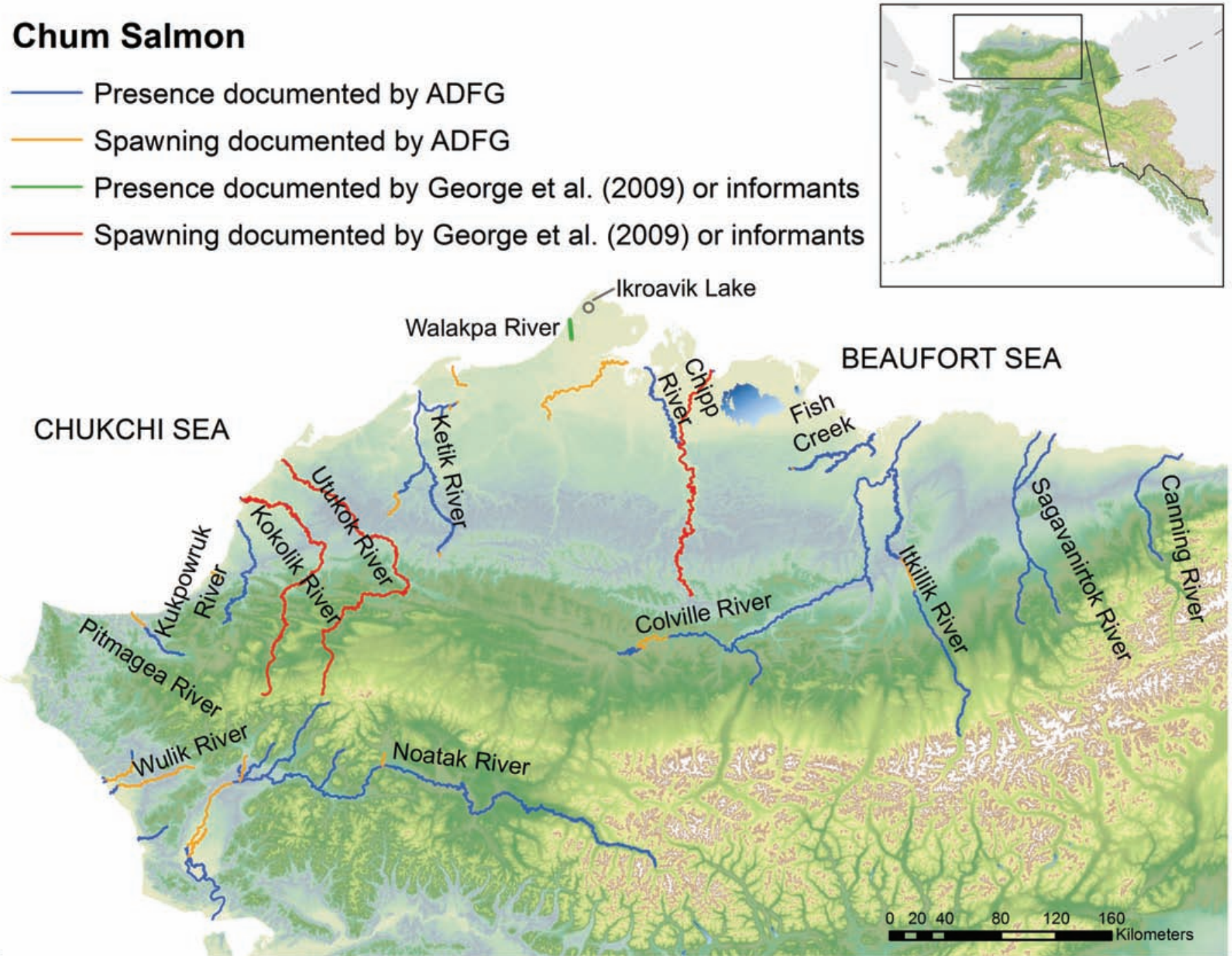

FIG. 6. The presence and spawning of chum salmon in stream systems in the North Slope region. Map produced by Leslie Jones, University of Alaska Anchorage and Christine Woll, The Nature Conservancy.

Prior to our study, several fishermen asked the NSBDWM staff to help them identify the different species of salmon. During our participant observation, we found that several fishermen used identification keys and kept personal logbooks of their harvests. Fishermen displayed pride in their ability to identify the different species of salmon. During an interview, one fisherman stated, "We've officially recorded every species incoming. I think all of them do get here." As a collective fishing community, the fishermen have worked with the biologists at the NSB-DWM, the Native Village of Barrow, Alaska Department of Fish and Game, and members of our project team to learn species identification and to strengthen the NSB-DWM's harvest records by helping to collect age, sex, weight, length, and genetics samples. Despite these recent measures to improve the detail of harvest records, not all Utqiagivik fishermen were interested in species-level identification. One informant, who is locally identified as an expert fisherman, stated, "If they're not humpies [pink salmon], I call 'em silvers, because they're silver... they all look the same to me."
Consistent with the way fishermen used the common English name "silver" to refer to more than one species of salmon, Iñupiaq nomenclature in this region has only two names for salmon-amaqtuuq and iqalugruaq. Amaqtuuq (explained to us as meaning "with a hump") is used to refer to pink salmon. Utqiagivik informants tended to use iqalugruaq to refer to bigger chum salmon. It is unclear if Iñupiaq Elders differentiated between chum salmon and Chinook salmon. In other Alaska Native language areas, there are five (or more) names for different salmon species. For example, in the Bristol Bay Yup'ik language region, all five species of Pacific salmon are named, with additional names used for salmon species in various life stages and sizes (Cotton, 2012). The occurrence of only two Iñupiaq names for salmon species in this region suggests that the other three species of salmon were not present or commonly found in the region.

In Nuiqsut, it appears that some fishermen use only one Iñupiaq name to refer to both salmon and Dolly Varden: iqalukpik (translated in George et al., 2009, as Dolly Varden 
char). During a discussion with a translator in Nuiqsut about the Iñupiaq names for pink salmon (amaqtuuq) and chum salmon (iqalugruaq), he stated, "These are not the names that we normally hear in Colville region." Rather iqalukpik, meaning a "big fish," is normally used to refer to salmon species. The majority of the Elders and fishermen we interviewed in Nuiqsut used the name iqalukpik to refer to salmon; however, two Elders did use the name iqalugruaq. One specifically used the term iqalugruaq to refer to chum salmon: "These got teeth. We call them iqalugruaq." When discussing pink salmon, one Elder in Nuiqsut stated, "They call it the iqalukpik. My grandfather would call them iqalukpik. He called them that because he did not know what else to call them...iqalukpik and iqalugruaq." Another Elder used the Iñupiaq term amaqtuuq to refer to pink salmon in Nuiqsut and mentioned specifically the hump characteristic of this species.

One Nuiqsut informant emphasized that several species, which he collectively called iqalukpik, migrate at the same time during the summer. As he explained, during some years, many salmon or Dolly Varden arrive, but during other years, they do not. While some Nuiqsut informants often discussed salmon species and Dolly Varden interchangeably, others were able to offer speciesspecific information on the presence and distribution of pink salmon and chum salmon in river and stream systems. Our findings of complicated and uncertain species identification are consistent with Bacon et al. (2009) and Mikow et al. (2016) who also note that species-level salmon identification can be challenging in the North Slope region, even in the western communities where salmon species are more commonly harvested.

\section{Salmon Use and Preferences}

As with any other food, harvested salmon are processed and prepared in a multitude of ways, depending on individual and family preferences and weather conditions. Traditionally, the Iñupiat did not cook much of their food. Fish were generally frozen or dried upon harvesting and eaten later with seal or whale oil. While fishing in the fall and winter months, harvesters make use of the sub-zero temperatures to freeze their catch whole. This frozen fish is generally eaten raw throughout the year as a staple of the Iñupiaq diet. During the summer months, fish are hung to dry at fish camp. People also place fish in ice cellars during the ice-free period. If ice cellars are not available, families use generators and freezers at camp to freeze fish. Smoking salmon has become more common in this region, as one respondent stated: "We're learning how to preserve. This year we smoked some of them [in a friend's electric smoker] ... the smoked salmon is really good, now that we can preserve it." Residents purchase commercially produced wood chips for smoking because wood is a scarce resource in this area. Pink salmon, chum salmon, and Chinook salmon are also often eaten fresh. Respondents mentioned eating these species raw as sushi or poke, grilled, baked, smoked, fried, or boiled. Several interviewees stated that they are learning new methods for preparing salmon.

Many informants stated early in our interviews their preference for non-salmon species, especially broad whitefish, Arctic cisco, Dolly Varden, and burbot; however, we found that residents expressed a wide range of preferences for salmon. As discussed previously, some fishermen view pink salmon as a pest species that clogs their gill nets. One informant said, "I didn't set my nets last year [2009], because they kept getting clogged up with pinks." Similarly, another interviewee said, "In years when there are a lot of pinks, I'll pull my nets because I don't want to have to deal with too many fish." One Nuiqsut informant stated: "Amaqtuuq [pink salmon], once in a while we get these, but we don't eat them." When asked why, she said: "On this broad part [the hump], they are stink. You have to [take] it out, that part, to cook [it]." We spoke with one informant who said that he did not set his net in 2009 and was told by an active fisherman during that year: "You ain't missing nothing. I ain't getting much, or it's a bunch of pinks." He replied: "Yeah, somebody needs to shoot them things." In particular, families who fish for broad whitefish in the Chipp River noted that they consider pink salmon to be a nuisance.

Evident in many of our interviews, however, are the evolving taste preferences for salmon in the Utqiagivik and Nuiqsut region. An Elder in Nuiqsut said that when she was growing up, people did not eat chum salmon. She said, "When I was growing up we feed the dogs with it. Iqalugruaq. But nowadays they sure like it." One young fisherman in Nuiqsut stated, "I love our salmon. That's basically why I go fishing in the summertime." A fisherman in Utqiagivik noted that he did not eat salmon until he was older and went into the military. He stated, "[We] never did have much salmon when I was growing up. Once I got out of high school and went into the military that's where most of us started eating salmon. Now it's a big thing, everybody wants salmon."

Our thematic content analysis of interview data yielded an unexpected finding. In our interviews about salmon use and knowledge, the most frequently coded theme was "nonsalmon species." Perhaps this finding is not surprising given the great importance of other culturally valued fish species for the Iñupiat and the relatively marginal role salmon currently play in subsistence (or traditional) fisheries in this region. Extensive knowledge exists about whitefish species. Interview respondents showed no difficulty identifying and describing all six Arctic species of whitefish, providing a description of when and where they are caught and when and where they spawn. Salmon identification and description, on the other hand, was more difficult. This attests to the long history of non-salmon species preference and the relatively recent targeting of salmon harvests in local fisheries.

In some interviews, we explored the topic of social status related to the harvest of salmon compared to other subsistence foods. Some informants directly discussed 
fishing and sharing in terms of status: "It's a bit of prestige to be able to catch a little bit more and give some away. You know, provide for a few people, which makes you a fully functional male adult in this society." In our participant observation in both Utqiagivik and Nuiqsut, we noticed the high status role occupied by whaling captains, captains' wives, and their families. We were curious about how highharvesting fishermen were viewed in the community. We explored this topic in some of our interviews, such as in this excerpt:

Interviewer: Do fishermen that bring in a lot of fish have a high status like a whaler or a hunter?

Interviewee: That's a really good question. My sense is no, never heard that. We haven't had a mayor of the North Slope Borough that hasn't been a whaling captain. It's almost a prerequisite. It's not the same for, "well I catch fish" ...salmon really isn't the thing, but I think there's a lot of status associated with the heavy hitters in the broad whitefish/aanaaktiq, fishery. Like [one of the local Elder men]. There was definitely status involved in that. That's the fish that's eaten at Nalukataq (spring whaling festival named for the blanket toss) and at Thanksgiving and Christmas. That's what people want to see in the bag when it's handed out for holidays and celebrations. There's quite a bit of status associated with that for sure. [One of the female Elders] dries a lot of fish. Broad whitefish, air dried pipsi, and so did [a few other families]. That stuff is gold.

Taken as a whole, this excerpt provides evidence that culturally valuable fish like broad whitefish are linked to status; but salmon are not coveted in Utqiagivik and Nuiqsut the same way as whitefish species. Whether this will change should salmon abundance increase markedly or if cultural preferences change remains to be seen.

Catching food to share is a central part of Iñupiaq culture and society, and catching and sharing salmon is no exception. Sharing goes far beyond giving food. Harvesting local resources is generally a cooperative activity; people share equipment, money for gas, time, and knowledge. Often many family members and friends are needed to set nets, pick fish from gill nets, process, and distribute the catch. Fishermen in Utqiagivik and Nuiqsut discussed the importance of sharing in a variety of ways reflected in the excerpt below:

Last year we gave away $75 \%$ of our catch. Our neighbors and everybody wanted fish, so I keep supplying.

Fishing, it helps when people are having hardship. I mostly give away whatever I can depending on my catch ... I only fish for what I handle and the rest I give away.

I keep gunnysacks of fish that we caught in the fall outside so when people ask for food or when a family is hungry we get a couple of them and supplement it with caribou to feed the family. We do this year-round ... [we] catch more than we need. We're fortunate enough; we're working and have snow machines.

It's part of our culture, sharing. Whatever you catch, you share. The thought is that if you share, you get more next time. That's just how my mom and dad raised me. When you catch something, share with family, share with Elders.

Many people maintain extensive sharing networks, which include local family members, friends, neighbors, business associates, and those who live outside the North Slope. Several interviewees mentioned giving fish away at the fire station, airport, or senior center when they caught more fish than expected in their nets. One Utqiagivik fisherman described his sharing patterns in the following way:

I usually feed the Elders first, with the whitefish. And then the widows who don't have any hunters, or somebody that's going to provide for them. They're getting fewer and fewer every year, but I still go around and take them over to the senior center, to the assisted living [center], so they'll have fresh fish and whatever. Then when I get salmon, I let people come and get 'em.

Local leaders encouraged us to explore the topic of commercial fishing in our interviews about salmon. They expressed concerns about how the economic value of salmon in other regions of the state paired with increasing catches of salmon in the North Slope may prompt interest in commercial fisheries development. In our interviews, many participants voiced concern about the potential effects commercial fishing would have on subsistence activities for the same resources in this region. Most fishermen we interviewed stated that they did not want commercialization of new fisheries to influence their lifestyle or to affect their important subsistence fisheries. Two respondents in Utqiagivik, however, did view local commercial fisheries development positively.

Commercial fishing is virtually absent in the North Slope region. Beginning in 1964, one family operated a smallscale commercial fishing operation in the coastal Colville Delta region that supplied a regional market for whitefish in Utqiagivik and other villages (MBC, 2004; Fechhelm et al., 2007; Helmericks, 2012). Despite the lack of formal commercial fisheries, informal sale of fish and fish products occurs. The exchange of subsistence fish for small amounts of cash in a noncommercial setting is referred to as "customary trade" and is protected under federal subsistence regulations in certain state subsistence fisheries (Magdanz et al., 2007). We saw evidence of infrequent and small sales of individual fish, packaged fish, or plates of cooked salmon meals. People post flyers on bulletin boards around town advertising fish for sale. Others announce on the VHF radio that they have salmon plate lunches for sale. 
TABLE 1. Summary of observations of salmon knowledge and use, and related findings.

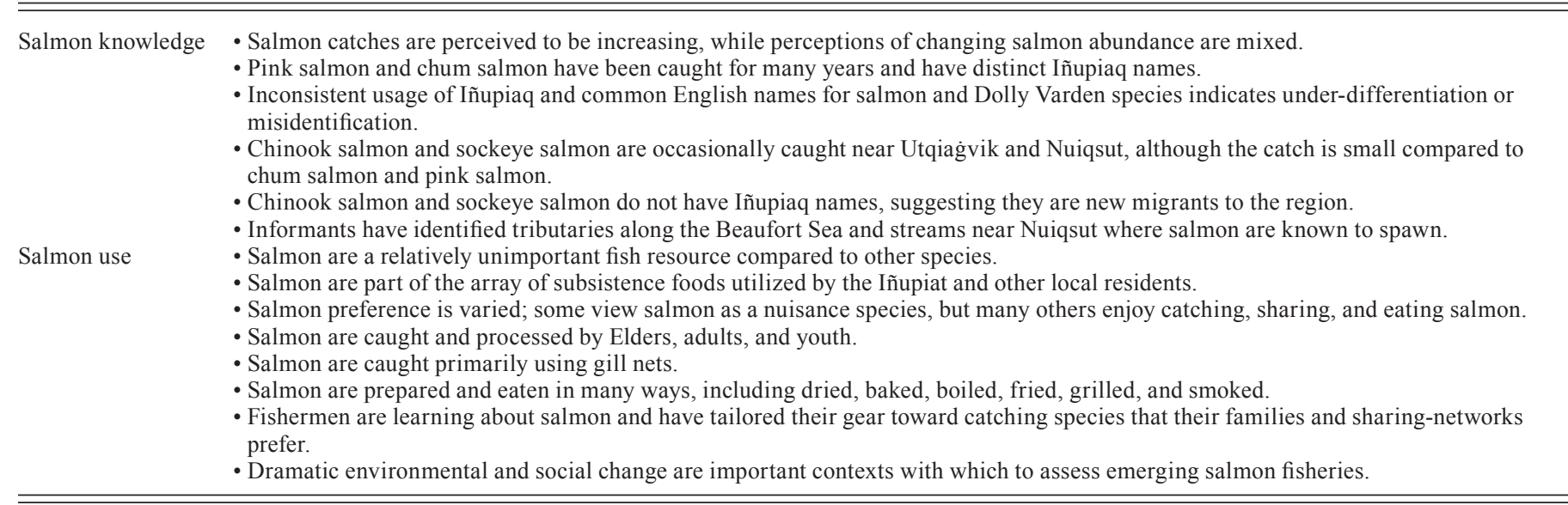

A plate of salmon, rice, and an "Eskimo donut" sold for $\$ 10$ in 2010, an absolute bargain compared to the cost of an average restaurant meal in Utqiagivik.

\section{SUMMARY AND CONCLUSION}

Arctic ecosystems are experiencing abrupt unprecedented changes (ACIA, 2005; Cochran et al., 2013; IPCC, 2014) and the appearance of new species in Arctic regions is a hallmark of global change. This study adds to the state of knowledge about Pacific salmon in the Arctic and emerging subsistence fisheries in the region in a time of social-ecological change. We summarize our key findings in Table 1. While perceptions of overall abundance patterns vary, salmon catches in Utqiagivik and Nuiqsut are undoubtedly increasing. Our ethnographic research and historical accounts indicate that pink salmon and chum salmon have been observed in traditional fisheries in the North Slope region for centuries; however, it appears to us that local use of these resources began to increase only recently, perhaps reflecting increasing fish abundances or changing preferences. Today, chum salmon and pink salmon are consistently targeted and harvested in Elson Lagoon near Utqiagivik and occasionally harvested in the Colville River and other regional river systems.

While the connections between salmon and Indigenous peoples in many regions have been severed by scarcity of fish resulting from habitat loss or destruction, some fishermen in Utqiagivik, and to a lesser extent in Nuiqsut, are increasingly connected to salmon by actively learning about salmon fishing, salmon identification, processing, and preparation. Salmon are harvested primarily using set gill nets, although some local fishermen are also starting to use rod and reel techniques to catch salmon. Methods for harvesting, processing, and preparing salmon are passed down through generations and across regions of Alaska, and some locals are experimenting with electric dryers and smokers. Fishermen in Utqiagivik and Nuiqsut often have a variety of techniques for salmon harvest and use. The preference and use of salmon species varies greatly among individual families. Many Elders and fishermen do not prefer pink salmon or chum salmon over whitefish, but fish that are caught tend not to be wasted. Catching fish, including salmon, to share is a primary motivator for many subsistence fishermen in both Utqiagivik and Nuiqsut. Fish are commonly distributed to family, neighbors, Elders, and the wider community.

Overall, salmon are currently a relatively unimportant subsistence resource in Utqiagivik and Nuiqsut. Although interviews were focused on salmon knowledge and use, the most frequently coded theme in our qualitative data analysis of the interviews in Utqiagivik and Nuiqsut was "non-salmon species," reflecting the cultural importance of other fish species in this region. In our interviews and participant observation, Elders and fishermen demonstrated a deeper understanding of morphology, run timing, harvest techniques, and a tighter cultural connection to whitefish and other fish species. Knowledge of the salmon species is increasing, but there is still misidentification of salmon species, even among expert fishermen. Salmon catches are especially important, however, to a few Utqiagivik fishermen who primarily harvest salmon.

Lastly, increased salmon catches are perceived to be one among a suite of environmental and social changes currently being experienced in Arctic Alaska (Moerlein and Carothers, 2012). Perceptions of environmental changes were a common theme throughout our interviews. Environmental change is perceived to be dramatic, increasing, and impacting local resource harvest, which is consistent with scientific records and predictions. Along with environmental change, we saw evidence of dramatic social and economic change in our ethnographic data. Our interviews revealed the effects of oil and gas development on fishing practices and traditional ways of life more generally, particularly in Nuiqsut. Nearly all active subsistence harvesters in Nuiqsut have had personal experiences with these impacts, and these impacts are increasingly affecting community wellbeing (see NRC, 2003; Stephen R. Braund \& Associates, 2009; Cotton 2012; Carothers et al., 2013). These broad environmental and social changes, along with consideration of local 
desires, such as protecting traditional hunting and fishing livelihoods from fisheries commercialization, provide an important context and waypoint with which to assess emerging fisheries in this region and beyond.

\section{ACKNOWLEDGEMENTS}

We thank the U.S. Bureau of Ocean Energy Management (OCS Study BOEM 2013-0015) and the Coastal Marine Institute, University of Alaska Fairbanks, College of Fisheries and Ocean Sciences, the Alaska Native Science \& Engineering Program, and the Alfred P. Sloan Foundation for project and student support. This study was published online by the Coastal Marine Institute in a final report to the funding agency, BOEM (Carothers et al., 2013). We thank the NSB-DWM, especially Taqulik Hepa and Joshua Bacon, the Native Village of Barrow, Native Village of Nuiqsut, the Kuukpik Subsistence Oversight Panel, the Iñupiat Heritage Center, Iñupiat History, Language and Culture Division, the Alaska Department of Fish and Game-especially Sverre Pedersen and Brittany Retherford. We thank those who helped with review and editing of Cotton's M.S. thesis, Milo Adkison, Craig George, Lara Horstmann, and Trent Sutton, as well as Chris Campbell and Ruth Post who assisted with review of our final agency report of this study. Finally, we extend our deepest thanks to all of our research participants who shared their knowledge and insights with us.

\section{APPENDIX 1}

The following table is available in a supplementary file to the online version of this article.

TABLE S1. List of thematic codes and counts of occurrences in qualitative interview data.

\section{REFERENCES}

ACIA (Arctic Climate Impact Assessment). 2005. Arctic climate impact assessment: Scientific report. New York: Cambridge University Press. 1042 p.

ADFG (Alaska Department of Fish and Game). 2018a. Anadromous waters catalog. https://www.adfg.alaska.gov/sf/SARR/AWC/

—. 2018b. Community Subsistence Information System: CSIS.

http://www.adfg.alaska.gov/sb/CSIS/

Aiken, Robert Sr. 1988. Oral history interview with Jack Winters and Billy Adams. March 9, 1988, Barrow, Alaska. Recorded for "Fishes utilized in subsistence fisheries in National Petroleum Reserve-Alaska project.” Barrow, Alaska: North Slope Borough Department of Wildlife Management.

Arundale, W.H., and Schneider, W.S. 1987. Quliaqtuat Inupiat Nunaninnin: The report of the Chipp-Ikpikpuk and Upper Meade River oral history project. Fairbanks: University of Alaska Fairbanks, Oral History Program.
Babaluk, J.A., Reist, J.D., Johnson, J.D., and Johnson, L. 2000. First records of sockeye (Oncorhynchus nerka) and pink salmon $(O$. gorbuscha) from Banks Island and other records of Pacific salmon in Northwest Territories, Canada. Arctic 53(2):161-164. https://doi.org/10.14430/arctic846

Bacon, J.J., Hepa, T.R., Brower, H.K., Jr., Pederson, M., Olemaun, T.P., George, J.C., and Corrigan, B.G. 2009. Estimates of subsistence harvest for villages on the North Slope of Alaska, 1994-2003. Barrow, Alaska: North Slope Borough Department of Wildlife Management.

http://www.north-slope.org/assets/images/uploads/ MASTER\%20SHDP\%2094-03\%20REPORT\%20FINAL\%20 and $\% 20 \% 20$ Errata $\% 20$ info\%20(Sept\%202012).pdf

Berkes, F. 2008. Sacred ecology, 2nd ed. New York: Routledge.

Bernard, H.R. 2006. Research methods in anthropology: Qualitative and quantitative approaches, $4^{\text {th }}$ ed. Lanham, Maryland: AltaMira Press.

BLM (Bureau of Land Management). 1982. Record of testimony: National Petroleum Reserve, subsistence hearing, Barrow, Alaska, November 22, 1982. Anchorage: U.S. Department of the Interior, BLM, NPR-A Program, Alaska State Office.

Bockstoce, J.R., ed. 1988. The journal of Rochfort Maguire, 1852-1854: Two years at Point Barrow, Alaska aboard HMS Plover in the search for Sir John Franklin, 2 vols. London: The Hakluyt Society.

Brewster, K., George, C., and Barrow Elders: Aiken, M., Brower, A., Sr., Itta, M., Itta, N., Leavitt, M.L., Leavitt, O., and Matumeak, W. 2008. Iñupiat knowledge of selected subsistence fish near Barrow, Alaska. Report prepared for the Bureau of Land Management through an assistance agreement to the North Slope Borough Department of Wildlife Management. http://www.north-slope.org/assets/images/uploads/Brewster_ Fish\%20TEK\%20paper.pdf

Brogan, J. 1979. Nuiqsut Paisanich, Nuiqsut heritage: A cultural plan. Prepared by the Arctic Environmental Data Center for the Village of Nuiqsut and the North Slope Borough Planning Commission and Commission on History and Culture.

https://www.blm.gov/sites/blm.gov/files/Planning_Alaska_ Nuiqsut_Paisangich_Heritage_Cultural_Plan.pdf

Brown, C.L., Braem, N.M., Kostick, M.L., Trainor, A., Slayton, L.J., Runfola, D.M., Mikow, E.H., et al. 2016. Harvests and uses of wild resources in 4 Interior Alaska communities and 3 Arctic Alaska communities, 2014. Technical Paper No. 426. Fairbanks: Alaska Department of Fish and Game, Division of Subsistence.

https://www.arlis.org/docs/vol1/M/972886420.pdf

Burch, E.S., Jr. 1998. The Iñupiaq Eskimo nations of Northwest Alaska. Fairbanks: University of Alaska Press.

Carothers, C., Cotton, S., and Moerlein, K. 2013. Subsistence use and knowledge of salmon in Barrow and Nuiqsut, Alaska. Final Report. OCS Study BOEM 2013-0015.

https://www.boem.gov/BOEM-Newsroom/Library/ Publications/2013/BOEM-2013-0015_pdf.aspx

Cheung, W.W.L, Watson, R., and Pauly, D. 2013. Signature of ocean warming in global fisheries catch. Nature 497:365-368. https://doi.org/10.1038/nature12156 
Cochran, P., Huntington, O.H., Pungowiyi, C., Tom, S., Chapin, F.S., III, Huntington, H.P., Maynard, N.G., and Trainor, S.F. 2013. Indigenous frameworks for observing and responding to climate change in Alaska. Climatic Change 120(3):557-567. https://doi.org/10.1007/s10584-013-0735-2

Cotton, S.S.D. 2012. Subsistence salmon fishing in Beaufort Sea communities. MS thesis, University of Alaska Fairbanks, Fairbanks, Alaska.

Craig, P.C. 1987. Subsistence fisheries at coastal villages in the Alaskan Arctic, 1970-1986. Technical Report 129. Anchorage, Alaska: USDOI, MMS, Alaska OCS Region.

http://alaska.portal.gina.alaska.edu/catalogs/3903subsistence-fisheries-at-coastal-villages-in-th

Craig, P., and Haldorson. L. 1986. Pacific salmon in the North American Arctic. Arctic 39(1):2-7. https://doi.org/10.14430/arctic2037

Dunmall, K.M., Reist, J.D., Carmack, E.C., Babaluk, J.A., HeideJørgensen, M.P., and Docker, M.F. 2013. Pacific salmon in the Arctic: Harbingers of change. In: Mueter, F.J., Dickson, D.M.S., Huntington, H.P., Irvine, J.R., Logerwell, E.A., MacLean, S.A., Quakenbush, L.T., and Rosa, C., eds. Responses of Arctic marine ecosystems to climate change. Fairbanks: Alaska Sea Grant, University of Alaska Fairbanks. https://doi.org/10.4027/ramecc.2013.07

Fall, J.A., Godduhn, A., Hutchinson-Scarbrough, L., Jones, B., Kukkonen, M., Runfola, D., Sill, L.A., Trainor, A., and Lemons, T. 2017. Alaska subsistence and personal use salmon fisheries: 2014 Annual Report. Technical Paper No. 427. Anchorage: Alaska Department of Fish and Game, Division of Subsistence. http://www.adfg.alaska.gov/techpap/TP427.pdf

Fechhelm, R.G., and Griffiths, W.W. 2001. Status of the Pacific salmon in the Beaufort Sea, 2001: A synopsis. Anchorage, Alaska: LGL Alaska Research Associates, Inc.

Fechhelm, R.G., Streever, B., and Gallaway, B.J. 2007. The Arctic cisco (Coregonus autumnalis) subsistence and commercial fisheries, Colville River, Alaska: A conceptual model. Arctic 60(4):421-429.

https://doi.org/10.14430/arctic199

Fechhelm, R.G., Raborn, S.W., and Link, M.R. 2009. Year 26 of the long-term monitoring of nearshore Beaufort Sea fisheries in the Prudhoe Bay region: 2008 annual report. Report for BP Exploration (Alaska) Inc. by LGL Research Associates, Inc., Anchorage, Alaska. 79 p.

Ford, J.D., and Furgal, C. 2009. Foreword to the special issue: Climate change impacts, adaptation and vulnerability in the Arctic. Polar Research 28(1):1 -9. https://doi.org/10.1111/j.1751-8369.2009.00103.x

George, C., Moulton, L., and Johnson, M. 2009. A field guide to the common fishes of the North Slope of Alaska. Version 1.5. Barrow, Alaska: North Slope Borough, Department of Wildlife Management.

Hansen, J., Sato, M., and Ruedy, R. 2012. Perception of climate change. Proceedings of the National Academy of Sciences 109(37):E2415-E2423.

https://doi.org/10.1073/pnas.1205276109

Helmericks Family. 2012. Helmericks family at Colville Village. http://www.goldenplover.org/index.html
Hendry, A.P., Castric, V., Kinnison, M.T., and Quinn, T.P. 2004. The evolution of philopatry and dispersal: Homing versus straying in salmonids. In: Hendry, A.P., and Stearns, S.C., eds. Evolution illuminated: Salmon and their relatives. Oxford: Oxford University Press. 52-91.

Hilborn, R., Quinn, T.P., Schindler, D.E., and Rogers. D.E. 2003. Biocomplexity and fisheries sustainability. Proceedings of the National Academy of Sciences 100(11):6564-6568.

https://doi.org/10.1073/pnas.1037274100

Holmes, R.M., Coe, M.T., Fiske, G.J., Gurtovaya, T., McClelland, J.W., Shiklomanov, A.I., Spencer, R.G.M., Tank, S.E., and Zhulidov, A.V. 2013. Climate change impacts on the hydrology and biogeochemistry of Arctic rivers. In: Goldman, C.R., Kumagai, M., and Robarts, R.D., eds. Climatic change and global warming of inland waters: Impacts and mitigation for ecosystems and societies. Somerset, New Jersey: John Wiley \& Sons, Ltd. 1-26.

https://doi.org/10.1002/9781118470596.ch1

Houde, N. 2007. The six faces of traditional ecological knowledge: Challenges and opportunities for Canadian co-management arrangements. Ecology and Society 12(2): 34.

https://doi.org/10.5751/es-02270-120234

Huntington, H.P. 1998. Observations on the utility of the semidirective interview for documenting traditional ecological knowledge. Arctic 51(3):237-242.

https://doi.org/10.14430/arctic1065

IPCC (Intergovernmental Panel on Climate Change). 2014. Climate change 2014: Synthesis report. Contribution of Working Groups I, II and III to the Fifth Assessment Report of the Intergovernmental Panel on Climate Change. Core Writing Team, Pachauri, R.K., and Meyer, L.A., eds. Geneva, Switzerland: IPCC. $151 \mathrm{p}$. https://doi.org/10.1017/cbo9781107415416

Irvine, J.R., Macdonald, R.W., Brown, R.J., Godbout, L., Reist, J.D., and Carmack, E.C. 2009. Salmon in the Arctic and how they avoid lethal low temperatures. North Pacific Anadromous Fish Commission Bulletin No. 5:39-50.

Kassam, K.A.S., and the Wainwright Tribal Council. 2001. Passing on the knowledge: Mapping human ecology in Wainwright, Alaska. Calgary, Alberta: Arctic Institute of North America. https://doi.org/10.11575/PRISM/35443

Laurel, B.J., Spencer, M., Iseri, P., and Copeman, L.A. 2016. Temperature-dependent growth and behavior of juvenile Arctic cod (Boreogadus saida) and co-occurring North Pacific gadids. Polar Biology 39(6):1127-1135. https://doi.org/10.1007/s00300-015-1761-5

Lemke, J.L., Seigle, J.C., Moulton, L.L., George, J.C., and Bacon, J.J. 2011. Fish harvest monitoring in two lagoon systems near Barrow, Alaska. Anchorage: ABR, Inc.-Environmental Research \& Services. PO Box 240268, Anchorage, Alaska 99524, USA.

Logerwell, E., Busby, M., Carothers, C., Cotton, S., DuffyAnderson, J., Farley, E., Goddard, P., et al. 2015. Fish communities across a spectrum of habitats in the western Beaufort Sea and Chukchi Sea. Progress in Oceanography 136:115-132.

https://doi.org/10.1016/j.pocean.2015.05.013 
Magdanz, J.S., Tahbone, S., Ahmasuk, A., Koster, D.S., and Davis, B.L. 2007. Customary trade and barter in fish in the Seward Peninsula area, Alaska. Technical Paper No. 328. Fairbanks: Alaska Department of Fish and Game, Division of Subsistence. http://www.adfg.alaska.gov/TechPap/TP328.pdf

MBC Applied Environmental Sciences. 2004. Proceedings of a Workshop on the Variability of Arctic Cisco (Qaaktaq) in the Colville River. OCS Study MMS 2004-033. Prepared by MBC Applied Environmental Sciences, Costa Mesa, California. Prepared for the U.S. Department of the Interior, Minerals Management Service, Alaska, OCS Region, Anchorage, Alaska 60 p. plus appendices.

https://www.boem.gov/BOEM-Newsroom/Library/ Publications/2004/2004_033.aspx

Mikow, E., Retherford, B., Godduhn, A., and Kostick, M.L. 2016. Exploring the subsistence fisheries of Point Lay and Wainwright, Alaska. Technical Paper No. 419. Fairbanks: Alaska Department of Fish and Game, Division of Subsistence. https://www.arlis.org/docs/vol1/M/965293136.pdf

Milner, A.M., Knudsen, E.E., Soiseth, C., Robertson, A.L., Schell, D., Phillips, I.T., and Magnusson, K. 2000. Colonization and development of stream communities across a 200-year gradient in Glacier Bay National Park, Alaska, U.S.A. Canadian Journal of Fisheries and Aquatic Sciences 57(11):2319-2335. https://doi.org/10.1139/f00-212

Mistry, J., and Berardi, A. 2016. Bridging Indigenous knowledge and scientific knowledge. Science 352(6291):1274-1275. https://doi.org/10.1126/science.aaf1160

Moerlein, K.J., and Carothers, C. 2012. Total environment of change: Impacts of climate change and social transitions on subsistence fisheries in Northwest Alaska. Ecology \& Society 17(1): 10 . https://doi.org/10.5751/es-04543-170110

Morita, S.H., Morita, K., and Sakano, H. 2001. Growth of chum salmon (Oncorhynchus keta) correlated with sea-surface salinity in the North Pacific. ICES Journal of Marine Science 58(6): $1335-1339$. https://doi.org/10.1006/jmsc.2001.1116

Moss, J.H., Murphy, J.M., Farley, E.V., Jr., Eisner, L.B., and Andrews, A.G. 2009. Juvenile pink and chum salmon distribution, diet, and growth in the northern Bering and Chukchi Seas. North Pacific Anadromous Fish Commission Bulletin No. 5:191-196.

https://doi.org/10.23849/npafcb6/219.234

Moulton, L.L., and Seigle, J.C. 2012. Surveys of fish in Elson Lagoon during 1996 and 2009-2010. Prepared for North Slope Borough, Department of Wildlife Management, Barrow, Alaska, by MJM Research and ABR, Inc. http://www.north-slope.org/assets/images/uploads/Elson Fyke_Report_1996_to_2010_2012_03_16.pdf

Murdoch, J. 1892. Ethnological results of the Point Barrow expedition. Ninth Annual Report of the Bureau of Ethnology. Washington D.C.: Government Printing Office.

Neakok, S., and Neakok, N. 1988. Oral history interview with John Burns. March 10, 1988, Barrow, Alaska. Recorded for "Fishes utilized in subsistence fisheries in National Petroleum Reserve-Alaska project.” Barrow, Alaska: North Slope Borough Department of Wildlife Management.
Nielson, J.L., Ruggerone, G.T., and Zimmerman, C.E. 2013. Adaptive strategies and life history characteristics in a warming climate: Salmon in the Arctic? Environmental Biology of Fishes 96(10-11):1187-1226. https://doi.org/10.1007/s10641-012-0082-6

NPFMC (North Pacific Fishery Management Council). 2009. Managing our nation's fisheries off the coast of Alaska. Anchorage, Alaska: NPFMC.

https://www.npfmc.org/wp-content/PDFdocuments/fmp/ Salmon/SalmonFMP311.pdf.

NRC (National Research Council). 2003. Cumulative environmental effects of oil and gas activities on Alaska's North Slope. Washington, D.C.: National Academies Press. https://doi.org/10.17226/10639

Parmesan, C. 2006. Ecological and evolutionary responses to recent climate change. Annual Review of Ecology Evolution and Systematics 37:637-669.

https://doi.org/10.1146/annurev.ecolsys.37.091305.110100

Pedersen, S., and Shishido, N.S. 1988. Subsistence study at Nuiqsut. Fairbanks, Alaska: Alaska Department of Fish and Game, Division of Subsistence.

Pess, G.R., Quinn, T.P., Gephard, S.R., and Saunders, R. 2014. Re-colonization of Atlantic and Pacific rivers by anadromous fishes: Linkages between life history and the benefits of barrier removal. Reviews in Fish Biology and Fisheries 24(3):881 -900. https://oi.org/10.1007/s11160-013-9339-1

Pinksy, M.L., Worm, B., Fogarty, M.J., Sarmiento, J.L., and Levin, S.A. 2013. Marine taxa track local climate velocities. Science 341(6151):1239-1242.

https://doi.org/10.1126/science.1239352

Riedlinger, D. 1999. Climate change and the Inuvialuit of Banks Island, NWT: Using traditional environmental knowledge to complement Western science. Arctic 52(4):430-432.

https://doi.org/10.14430/arctic948

Ruggerone, G.T., and Irvine, J.R. 2018. Numbers and biomass of natural-and hatchery-origin pink salmon, chum salmon, and sockeye salmon in the North Pacific Ocean, 1925-2015. Marine and Coastal Fisheries 10(2):152-168.

https://doi.org/10.1002/mcf2.10023

Ruggerone, G.T., Nielsen, J.L., and Bumgarner, J. 2007. Linkages between Alaskan sockeye salmon abundance, growth at sea, and climate, 1955-2002. Deep Sea Research Part II: Topical Studies in Oceanography 54(23-26):2776-2793.

https://doi.org/10.1016/j.dsr2.2007.08.016

Schindler, D.E., Hilborn, R., Chasco, B., Boatright, C.P., Quinn, T.P., Rogers, L.A., and Webster, M.S. 2010. Population diversity and the portfolio effect in an exploited species. Nature 465:609-612. https://doi.org/10.1038/nature09060

Schtickzelle, N., and Quinn, T.P. 2007. A metapopulation perspective for salmon and other anadromous fish. Fish and Fisheries 8(4):297-314.

https://doi.org/10.1111/j.1467-2979.2007.00256.x 
Simpson, J. 1988 [1885]. Observations on the western Esquimaux and the country they inhabit; from notes taken during two years at Point Barrow, by Mr. J. Simpson, Surgeon. In: Bockstoce, J., ed. The journal of Rochfort Maguire, 1852-1854: Two Years at Point Barrow, Alaska, aboard HMS Plover in the search for Sir John Franklin, Vol. 2, Appendix 7.

Spradley, J.P. 1979. The ethnographic interview. New York: Holt, Rinehart, \& Winston.

Steele, M.A., Zhang, J., and Ermold, W. 2010. Mechanisms of summertime upper Arctic Ocean warming and the effect on sea ice melt. Journal of Geophysical Research 115, C11004. https://doi.org/10.1029/2009JC005849

Stephen R. Braund \& Associates. 2009. Impacts and benefits of oil and gas development to Barrow, Nuiqsut, Wainwright, and Atqasuk harvesters. Report prepared for North Slope Borough, Department of Wildlife Management. Anchorage: Stephen R. Braund \& Associates.

http://www.north-slope.org/assets/images/uploads/ Braund\%20NSB\%20Oil\%20and\%20Gas\%20Impacts\%20 July\%2009.pdf

___ 2010. Subsistence mapping of Nuiqsut, Kaktovik, and Barrow. OCS Study MMS 2009-003. Anchorage: U.S. Department of the Interior, Minerals Management Service, Alaska OCS Region.

http://www.north-slope.org/assets/images/uploads/ Braund\%202010\%20Beaufort\%20maps\%20MMS_MP_ Final_Report_Apr2010.pdf
Stephenson, S.A. 2006. A review of the occurrence of Pacific salmon (Oncorhynchus spp.) in the Canadian western Arctic. Arctic 59(1):37-46. https://doi.org/10.14430/arctic362

U.S. Census Bureau. 2012. Alaska community database, community information summaries. http://commerce.alaska.gov/dca/commdb/CF_CIS.htm

Waples, R.S., Pess, G.R., and Beechie, T. 2008. Evolutionary history of Pacific salmon in dynamic environments. Evolutionary Applications 1(2):189-206. https://doi.org/10.1111/j.1752-4571.2008.00023.x

Wassmann, P., Duarte, C.M., Agusti, S., and Sejr, M.K. 2011. Footprints of climate change in the Arctic marine ecosystem. Global Change Biology 17(2):1235-1249. https://doi.org/10.1111/j.1365-2486.2010.02311.x

Williams, P., Sr., Pitka, E., Adams, C., Jr., Britton, K., Black, J., Stevens, C., Brewer, J.P., II, Frank, K., and Hayton, A. 2016. Bridging yesterday with tomorrow: Understanding traditional ecosystem management practices and their application to contemporary sustainable boreal ecosystem management. Fort Yukon, Alaska: Council of Athabascan Tribal Governments. $31 \mathrm{p}$.

Wolfe, R.J., Fall, J.A., Fay, V., Georgette, S., Magdanz, J., Pedersen, S., Pete, M., and Schichnes, J. 1986. The role of fish and wildlife in the economies of Barrow, Bethel, Dillingham, Kotzebue, and Nome. Technical Paper No. 154. Juneau: Alaska Department of Fish and Game, Division of Subsistence. 